\author{
Ibtisam A. Hasan \\ Electromechanical Eng. Dept. \\ University of Technology, \\ Baghdad, Iraq. \\ dribtisamahmed58@gmail.com
}

\section{Hatam Karem}

Electromechanical Eng. Dept. University of Technology, Baghdad, Iraq

\section{Sahar R. Fafraj \\ Electromechanical Eng. Dept. University of Technology, Baghdad, Iraq. dr.saharalsakini@yahoo.com}

Received on: 15/11/2018 Accepted on: 10/01/2019 Published online: 25/12/2019

\section{Develop and Analyze a Model for Teaching According to the Flipped Class Approach}

Abstract- In this paper, the flipped class strategy has been designed for electromechanical devices lessons. As a first step towards flipping the classroom two lessons are selected from the curriculum common. Delivering lecture content of selected topics before coming to class through notes and other media has been done, while the class time is effectively engaged in highlevel thinking. The first step is to try to create the required educational materials to provide content related to topics outside of classroom environment. The second step is to design effective learning strategies for Problem Solving. JIGSAW method has been used for the in the classroom activity. The second step is to design effective learning strategies for Problem Solving. JIGSAW method has been used for the in the classroom activity. Presently, there are limited researches on the effect of the flipped classroom model of Engineering Education. A course such as electromechanical devices that covers problem-solving and design aspects, demands time for teaching the concepts in an effective and efficient way and can be better taught through the use of the flipped classroom approach. This work will be useful for faculty members in other Engineering departments.

Keywords- Flipped classroom, Designing, Out classroom activity, In classroom activity, active learning strategies

How to cite this article: Ibtisam A. Hasan, Hatam Karem, and Sahar R. Fafraj, "Develop and analyze a Model for Teaching according to Flipped Class Approach," Engineering and Technology Journal, Vol. 37, Part C, No. 4, pp. 436-440, 2019.

\section{Introduction}

Teaching is a key component of educational planning and it plays as the main role in the management of educational plans [1]. The expression "education" is understood to cover all organized and methodical communication prepared to create learning [2]. At the present time, teaching effectiveness is a significant topic because efficient teaching leads to good learning for students. It has turned out into more important with an increased emphasis on quality in the outputs of higher education. In this paper, the flipped classroom approach is designed to teach heat transfer courses. The flipped classroom approach has become an increasingly common method for student learning since many tools are available online for students in order to access knowledge and learning apart from the traditional classroom, [3, 4, 5, 6 and 7]. The main purposes for applying the flipped classroom are to engage all students in energetic learning which leads to focus on students' application of theoretical conceptual rather than on factual recall. The mentioned method will be used well when the proper methodical and pedagogic principles were put in implementation within the process of picking and creating of teaching content. "Flipped classroom" is an instructional model where the elements of education (homework and lecture) are reversed. The students watch a short video or powerpoint file about the lectures' topic at home before the date of the class time, while classroom time is allocated to projects, exercises, or discussions, it calls JIGSAW technique. It is a method for organizing the activity of the classroom to make students rely on each other for success. [8, 9, 10 and 11]. The video lecture is often considered as the main element of the flipped approach. These lectures are either constructed by the instructor and published online or elected from an online depot. Whereas previously recorded lectures could be a reference for students such as an audio lecture or a digital audio file made available on the Internet for downloading to a computer as well as a powerpoint file. The ease access and view of podcast make it today ubiquitous. With these facilities, so the flipped classroom becomes a viable model. From reviewing research literature in this field, the flipped classroom found to be a good learning strategy because it can actually improve the experience of student learning through increased interactivity, [12]. They also concluded to the following results; educators 
maybe not having a full understanding for translating the flipped classroom into practice. There was a misunderstanding of essential elements needed for successful flipping of the class and how to link between pre-education and sessions learning, [13]. The present work seeks to develop a model of flipped class which helps to illustrate the practice and informing the designing detail of the model, confessing that there is no single tactic to flip the learning.

\section{Teaching Methodology of the Flipped Classroom}

Flipped learning seems an attractive method in higher education, due to its ability to rely on different learning theories like problem-based learning, active and cooperative learning and peer-assisted learning, [14]. In a flipped classroom, students carry out some preparation work before the date of the lecture by seeing videos, podcasts or by reading the course material (foundational knowledge) which is then utilized in class as interactive tasks, aimed for dealing with high skills thinking in the classroom, see Figure 1. Foundational knowledge is usually prepared for them by their professors or from the knowledge available on the internet. Professors guide students by clarifying that knowledge and actively applying during the classroom by doing a lot of efficient and interactive learning about the topic in a classroom. There is growing evidence that this teaching method leads up to increase in student levels of achievement, engagement, and interest $[6,7,9,10,13]$. The importance of using this model is giving the ability for the creator to develop the course stage depending on the students' assessment results. Fig. 1 shows the main steps of the flipped classroom design. Step 1 through 3 represents an activity outside the classroom and steps $4-6$ are for the activity within the classroom in a flipped model.

\section{I.The design activity of the out Classroom:}

1) Identify topics.

2) Create a short video or PowerPoint file for each topic and for 10-15 mints.

3) Publish relevant literature and videos in the Learning Management System.

4) Listed out the main concepts that should be covered by the instructor about topics of course.

5) Determine the educational objectives of the activity outside the classroom.

6) Assessment students for their activity outside the classroom.

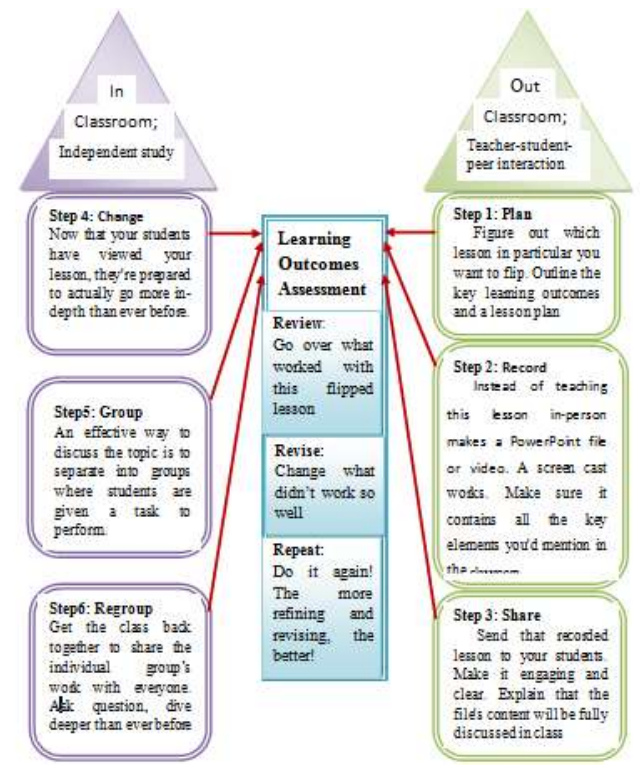

Figure 1: The learning theory in the Flipped Classroom

\section{II.The in Classroom Activity Design}

1) Link the activities Outside the Classroom and In-Class by providing a summary.

2) Choose an active education methodology: active education requires students to go beyond listening and writing of notes.

3) Determine learning aims inside class activity.

4) Explanation of active education strategy.

5) The lecturer provides guidance on topics in the classroom.

6) Students should work in groups during solving the problems: students cooperate with each other to resolve problems, with discussion, involving inquiry-based learning, genuine and discovery learning.

7) Students must speak, write, think and demonstrate their thoughts.

8) Students participate in analysis, evaluation, and creation (higher thinking).

9) In order to create an interactive state during class time, the students should be got feedback in class about their contribution, both from instructor and peers.

10) Applying an assessment method for the activity of our classroom.

\section{Design Lesson Activities for Electromechanical Devices}

We have designed the activities of electromechanical devices lesson that are useful as out and in-class activity for flipping the class. There are two lessons as part of the present flipped class, each one deals with a side related to content decisions. The activity of our class at most covers the lower levels of understanding and remembering. While the students in class activity 
are engaged in higher-level thinking (applyAnalyze -), see Figure 2.

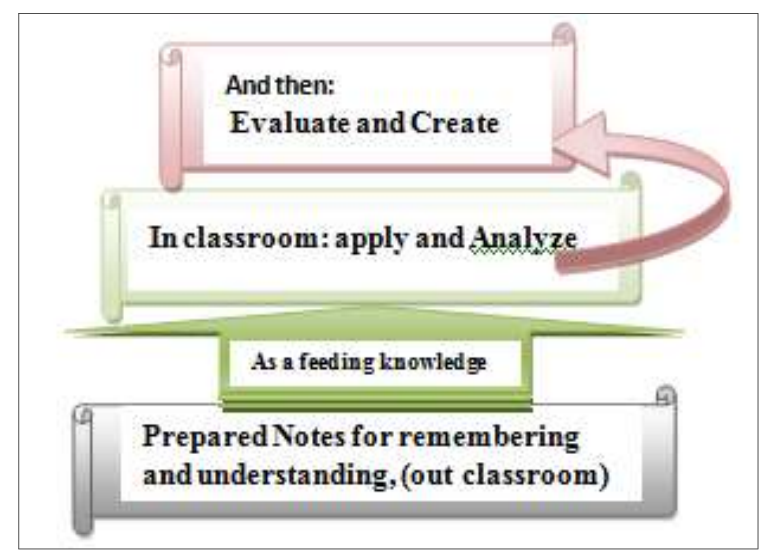

Figure 2: Levels for Out of Class \& In class activity

I.The prepared steps for out classroom activity

The first step to the flipped class strategy for the selected topics mentioned above, the topics learning objectives are written. And the required notes were done for relating topics through the official website of the electromechanical department.

\section{II.The prepared steps for in classroom activity}

The topic is divided into 4 subtopics and the teacher divides the students as per the following:

Step:1 Students are divided into a group of 3 or 4 . The group should be diverse in terms of gender, ability, and skill.

Step:2 Lesson is divided into $4-5$ segments (one for each member)

Step:3 Each student is assigned one segment to learn. Each student should only have direct access to their own segment.

Step:4 Students should be given time to read their segment to become familiar with it.

Step:5 Temporary expert's groups should be formed in which one student from each group joins other students assigned to the same segment. Students in this expert group should be given time to discuss the points of their segment.

Step:6 Students come back to their group and present their segment to the group.

\section{III.The designed lessons}

Two lessons of Curriculum common of electromechanical devices in the electromechanical department are designed.
Flipped Class Technology is used while developing Out-of-Class and In-class activities.

Lesson 1: Design pressure measurement devices as a control system

- Explain the basic steps of design a pressure measurement device as a control system.

- determine the transfer function and block diagram for each component and overall T.F. and B.D.

- determine time constant and response (transient and steady state).

- Explain system stability it's effect.

- Illustrate requirement $\mathrm{s}$ of maintenance and development.

- Write a report includes; introduction, calculation, materials selection, and discussion.

Table 1: Outcome (a) Scoring Rubric

\begin{tabular}{|c|c|c|c|c|}
\hline & I Furet & 3 Shen & 2 Trupens & 13her \\
\hline $\begin{array}{l}\text { toud } \\
\text { ande } \\
\text { sio }\end{array}$ & 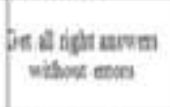 & 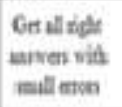 & $\begin{array}{c}\text { Cas ve vion } \\
\text { tict } \\
\text { ayen }\end{array}$ & 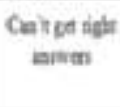 \\
\hline $\begin{array}{l}\text { Tre of } \\
\text { nina }\end{array}$ & 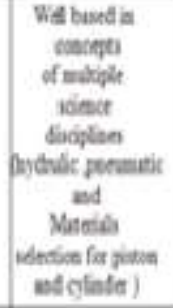 & 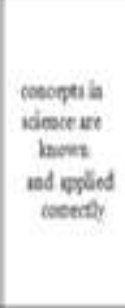 & 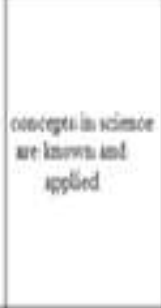 & $\begin{array}{l}\text { Cent iply } \\
\text { idesc } \\
\text { cescept }\end{array}$ \\
\hline $\begin{array}{l}\text { Tued } \\
\text { topto } \\
\text { nente }\end{array}$ & 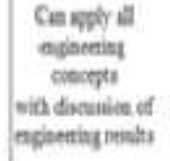 & 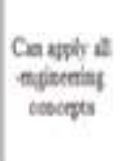 & 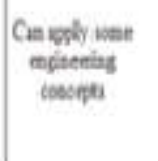 & 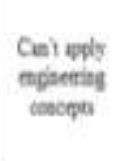 \\
\hline
\end{tabular}

30 report were submitted; each group has 3-4 students. where the differential equation solution and Laplace transformation are the math concepts. also, the science concepts are (equations., calculating forces and displacements on piston and cylinder). while the engineering concepts are (calculating T.F. and B.D. for each component and overall, then the determination of response and stability to achieve maintenance and develop.

Outcome (e): An ability to identify, formulate and solve engineering problems (level measurement devices as control system block diagram, transfer function, response, stability, E s.s)

20 student work as a team and reports submitted, each group has 3-4 students. Where the differential equation solution and Laplace transformation are the math concepts .also the science concepts are (equations. Calculating forces and displacements on piston and cylinder).while the engineering concepts are 
(calculating T.F. and B.D. for each component and overall, then the determination of response and stability to achieve maintenance and development ).

Table 2: Outcome (e) Scoring Rubric

\begin{tabular}{|c|c|c|c|c|}
\hline & 4 Exceeds & 3-Meets & 2-Progerssing & 1-Below \\
\hline $\begin{array}{l}\text { Extructs } \\
\text { exgineting } \\
\text { problea frina } \\
\text { maltifioseded } \\
\text { problen }\end{array}$ & 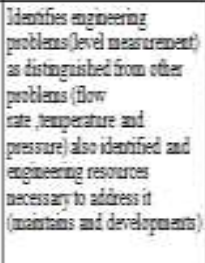 & 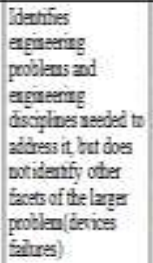 & 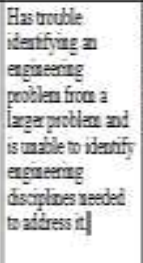 & 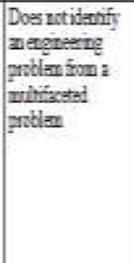 \\
\hline $\begin{array}{l}\text { Can set up } \\
\text { sohiteru approsech }\end{array}$ & 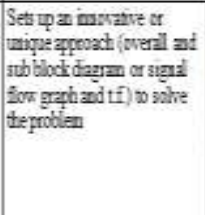 & 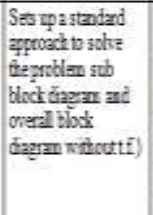 & 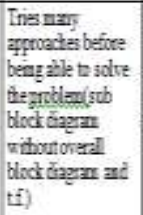 & 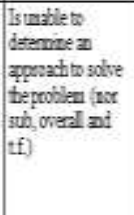 \\
\hline $\begin{array}{l}\text { Can solhe } \\
\text { ergineting } \\
\text { problicas }\end{array}$ & 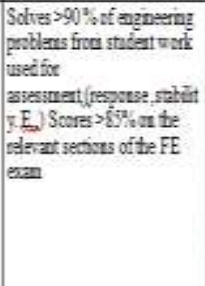 & 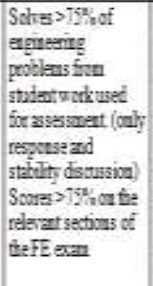 & 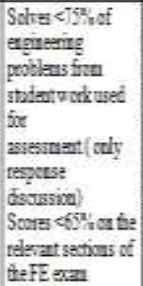 & 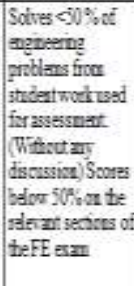 \\
\hline
\end{tabular}

Lesson 2: formulate and solve engineering problems (level measurement devices as control system block diagram, transfer function, response, stability, E s.s(

Performance indicators:

1) Can extract an engineering problem from the multifaceted problem.

2) Can take an engineering problem and set up an approach to solving it.

3) Can solve an engineering problem appropriate for the B.Sc. level

4) Assessment Tools: PI 1: Simulation, PI 2: Student Work

FE exam (all graduating students are required to take the exam)

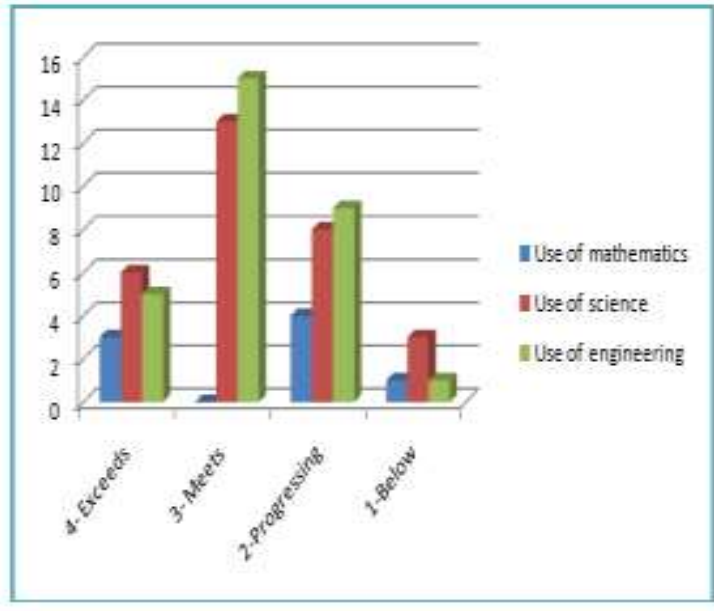

Figure 3: Outcome of students

Table1 : Outcome (e) assessments

\begin{tabular}{|c|c|c|c|c|c|}
\hline & 4. Bceets & 3- Neess & 2.9mersing & 1-below & \\
\hline $\begin{array}{l}\text { Distinguished from } \\
\text { other problems }\end{array}$ & 7 & 9 & 2 & 2 & $\begin{array}{l}7^{*} 4+9 * 3+2 \cdot 2+2 * 161, \\
\text { ave }=61 / 20=3.05\end{array}$ \\
\hline Solution approech & 5 & 10 & 4 & 1 & $\begin{array}{l}5^{*}+4+10^{*} 3+4 * 2+1 * 1=59 \\
\text { ave }=59 / 20=2.95\end{array}$ \\
\hline $\begin{array}{l}\text { Solve engineering } \\
\text { problems }\end{array}$ & 6 & 9 & 4 & 1 & $\begin{array}{l}6^{*}+4=9^{*} 3+44^{*}+1^{*} 1=60 \\
\text { ave }=50 / 20=3\end{array}$ \\
\hline
\end{tabular}

\section{Conclusions}

The flipped classroom that has recently become popular for teaching practice has grown popular across in all teaching disciplines and all age levels. Flipped Classroom approach offers a good use of technology; the lectures are got out of the classrooms and become in the hands. so the focus becomes more for utilizing the time of class effectively. That will lead to better assimilation of different participation's learners with problembased learning because it lets students to take responsibility for learning as well as increased interaction between teacher and students.

Current work offers limited papers in the topics of electromechanical devices to teach according to the flipped class approach. The suggested designed model shown in this work would absolutely result for higher learning capabilities, crucial thinking and solving the problems that will improve students' performance.

\section{References}

[1] N.S. Bidabadi, A.R. Isfahani, A. Rouhollahi, and R. Khalili, "Effective Teaching Methods in Higher Education: Requirements and Barriers," J Adv Med Educ Prof.; 4(4): 170-178, 2016. 
[2] J.F Mayberry, "The design and application of effective written instructional material: a review of published work," 2007.

[3] http://www.edudemic.com/guides/flippedclassroomsguide/

[4] A review of flipped classroom research, practice and technologies,

https://www.hetl.org/a-reviewof- flipped-classroomresearch-practice-andtechnologies/

[5] http://www.uq.edu.au/teach/flippedclassroom/ whyflip.html

[6] M.J. Lage, G.J. Platt, and M. Treglia, "Inverting the classroom: A gateway to creating an inclusive learning environment," The Journal of Economic Education 31.1, 30-43, 2000.

[7] N. Hamdan, P. McKnight, K. McKnight, \& K.M. Arfstrom, "A Review of Flipped Learning," Retrieved Jan 6, 2014, http://flippedlearning. Org/review, 2013.

[8] https://www.collegestar.org/modules/flippedclassroom

[9] Perception of Flipped Classroom Model among Year One and Year Three Health Science Students International Journal of Information and Education Technology, Vol. 6, No. 3, March 2016.

[10] A review of Flipped Learning,http://flippedlearning.org/wpcontent/ uploads/2016/07/LitReview_FlippedLea rning.pdf

[11] S. Zappe, R. Leicht, J. Messner, T. Litzinger \& H.W. Lee, "Flipping" the classroom to explore active learning in a large undergraduate course. In Proceedings, American Society for Engineering Education Annual Conference \& Exhibition, 2009.

[12] J. O'Flaherty, \& C. Phillips, The use of flipped classrooms in higher education: A scoping review. The Internet and Higher Education, 25, 85-95, 2015.

[13] M. Jenkins, R. Bokosmaty, M. Brown, C. Browne, Q. Gao, J. Hanson, \& K. Kupatadze, "Enhancing the design and analysis of flipped learning strategies," Teaching \& Learning Inquiry, 5, 1, 2017.

[14] O. JONES, "Flipping classrooms! The potential for flipped learning approaches in implementing the new Learning and Teaching strategy," https://yorkforum.org, 2015. 